\title{
Pemetaan Lokasi Kejadian dalam Sistem Deteksi Kejadian dengan Data Twitter Menggunakan Teori Graf
}

\author{
${ }^{1}$ Fatra Nonggala Putra, ${ }^{2}$ Iza Arfiana Fauziah \\ Program Studi Ilmu Komputer, Universitas Nahdlatul Ulama Blitar, \\ Blitar, Indonesia
}

Email: 1fatranp@unublitar.ac.id, ${ }^{2}$ izaarfiana@gmail.com

\begin{tabular}{l}
$\overline{\text { Tersedia Online di }}$ \\
\hline http://www.jurnal.unublitar.ac.id/i \\
ndex.php/briliant
\end{tabular}

Sejarah Artikel

Diterima pada 30 April 2020

Disetujui pada 15 Mei 2020

Dipublikasikan pada 30 Mei 2020

Hal. 431-441

\begin{tabular}{l}
\hline Kata Kunci: \\
\hline Sistem deteksi kejadian; twitter; \\
FASM; graph \\
\hline \\
\hline DOI: \\
\hline http://dx.doi.org/10.28926/briliant. \\
v3i4.472 \\
\hline
\end{tabular}

\begin{abstract}
Abstrak: Sistem deteksi kejadian dengan data twitter sebagai data masukannya telah banyak diteliti sebelumnya. Suatu informasi kejadian dapat dikategorikan sebagai kejadian penting adalah jika minimal terdapat informasi lokasi/tempat kejadian. Dalam sebuah tweet, seringkali terdapat lebih dari satu entitas lokasi kejadian karena kejadiannya memiliki dampak lebih dari satu titik lokasi. Hal ini berarti ada keterhubungan atau relasi antar lokasi kejadian sehingga diperlukan cara merubah relasi yang berupa teks ke dalam bentuk graf. Selain itu, banyak juga suatu informasi kejadian menulis entitas lokasi yang dengan ejaan yang berbeda atau terdapat kesalahan penulisan. Hal ini menyulitkan pemetaan lokasi terjadinya kejadian ke dalam maps karena entitas lokasi tidak terdapat di dalam gazetteer. Maka dari itu, diperlukan standardisasi entitas nama lokasi kejadian dengan Fast Approximate String Matching (FASM) dan
\end{abstract} mengkonversi relasi antar lokasi ke dalam graf. Dalam penelitian ini menunjukkan bahwa merubah relasi antar lokasi ke dalam bentuk graf yang sebelumnya telah dilakukan standardisasi entitas nama lokasi sangat memudahkan sistem dalam pemetaan atau memvisualisasikan informasi lokasi kejadian ke dalam GoogleMaps.

\section{PENDAHULUAN}

Penduduk indonesia setiap tahunnya mengalami peningkatan jumlah populasi penduduk yang pada tahun 2019 jumlah pendudukan Indonesia diproyeksikan mencapai 271 jiwa. Dengan banyaknya penduduk di Indonesia, membuat kepadatan dan mobilitas masyarakatnya menjadi sangat tinggi terutama di kota-kota besar. Tingginya mobilitas menimbulkan dampak meningkatnya jumlah kecelakaan dan kemacetan di jalan raya. Disamping itu, kemacetan adalah hal yang tidak diinginkan oleh setiap orang. Setiap orang selalu berupaya secepat mungkin mencapai tempat kerja, tempat wisata, rumah, dan tempat lainnya yang menjadi tujuannya.

Beberapa cara telah dilakukan untuk memudahkan masyarakat menghindari kemacetan atau paling tidak memberikan informasi seperti kemacetan, kebakaran, dan banjir di daerah tertentu. Mulai dari cara konvensional dengan menempatkan sensor-sensor deteksi dan kamera hingga pemanfaatan data media sosial seperti Twitter dan Facebook (Gelernter \& Balaji, 2013; Gu, Qian, \& Chen, 2016; Li et al., 2017). Pemanfaatan media sosial sebagai sumber informasi dibandingkan dengan cara konvensional dengan sesnsor dan kamera dianggap 
lebih murah dan cepat. Twitter merupakan salah satu microblogging populer untuk pertukaran informasi penggunanya. Twitter mampu menghasilkan 500 juta tweet per harinya dan setiap bulannya terdapat 330 juta pengguna aktif, maka pantaslah jika twitter menyandang microblogging terpopuler untuk saat ini ( $\mathrm{Gu}$ et al., 2016). Pada saat ini, pemanfaatan Twitter salah satunya adalah sebagai media berbagi informasi kejadian penting oleh penggunanya yang mayoritas kejadian tersebut memang diketahui secara langsung oleh si pengguna. Ada 2 jenis pengguna dalam media sosial yaitu pengguna sebagai individu dan pengguna sebagai representasi perusahaan ataupun lembaga seperti akun BMKG, Dishub, Radio, dan lain-lain.

Sejumlah penelitian dengan memanfaatkan data twitter sebagai pendeteksi kejadian secara realtime telah dilakukan antara lain oleh Yiming $\mathrm{Gu}$ dkk dengan melakukan pengklasifikasian biner menggunakan semi-Naive Bayes terhadap data stream twitter. Pada Hasby dan Khodra melakukan ekstraksi lokasi kemacetan menggunakan named-entity-recognition (NER) dan relation extraction (RE) yang kemudian digunakan untuk mencari jalur perjalanan lain yang paling optimal (Hasby, Khodra, \& Purwarianti, 2013). Penelitian lainnya, melalukan ekstrasi informasi data stream twitter menggunakan NeuroNER untuk mendeteksi entitas lokasi kejadian dalam teks tweet dan RCNN untuk mengklasifikasin tweet sebagai tweet informatif atau tweet non-informatif (Putra \& Fatichah, 2018).

Pada beberapa penelitian deteksi kejadian belum memperhitungkan kesalahan penulisan nama lokasi sehingga jika terjadi kesalahan penulisan lokasi, maka tidak akan bisa dipetakan ke dalam peta atau maps. Dalam sebuah teks tweet yang melaporkan suatu kejadian, kadangkala menyebut satu nama lokasi lebih dari satu kali namun berbeda dalam menulisnya atau terjadi kesalahan penulisan. Hal ini sangat disayangkan jika ada informasi kejadian penting tapi tidak dapat di visualisasikan ke dalam map dikarenakan ada kesalahan penulisan nama lokasi kejadian.

Dilain sisi, setiap informasi kejadian haruslah minimal mempunya 1 (satu) entitas lokasi. Dengan memanfaatkan teori graf, suatu lokasi dapat dianggap sebagai sebuah node. Suatu kejadian bisa berdampak pada satu tempat tertentu atau beberapa tempat sekaligus yang berhungan. Hubungan antar lokasi ini disebut sebagai relasi. Jadi, node satu dengan node lainnya akan dihubungkna dengan jenis relasi tertentu. Ada node sebagai titik awal, titik antara, dan node sabagai titik akhir.

Berdasarkan paparan permasalahan di atas, maka diperlukan standardisasi nama atau entitas lokasi kejadian berdasarkan gazetteer untuk memastikan entitas lokasi tersebut valid. Hal ini dilakukan untuk memudahkan dalam memetakan lokasi suatu kejadian ke dalam graf sebelum divisualisasikan ke dalam Google Maps.

\section{METODE}

Bab ini memaparkan metode yang digunakan untuk menyelesaikan permasalahan pada visualisasi lokasi kejadian pada sistem deteksi kejadian dengan menggunakan teori graf. Tahapan ini dibagi menjadi 3 subbab yaitu; 1) persiapan data, 2) standardisasi entitas lokasi, dan 3) konversi lokasi ke dalam bentuk graf. Penjelasan setiap subbab sebagai berikut:

\section{A. Persiapan Dataset}

432 BRILIANT: Jurnal Riset dan Konseptual

Volume 5 Nomor 2, Mei 2020 
Pada penelitian ini ada dua jenis data yang dibutuhkan yaitu: 1) data Tweet, dan 2) data Gazetteer yang pada penelitian ini hanya fokus pada kota Surabaya. Setiap jenis data tersebut perlu diolah dahulu melalui tahapan praproses untuk memastikan data yang akan diolah merupakan data bagus yang dapat digunakan oleh sistem.

1) Data Tweet

Pengambilan data tweet dilakukan menggunakan API Twitter yang dengan bantuan library dari python yaitu tweepy. Target dari pengambilan data ini adalah berdasarkan ID Twitter langsung seperti akun Radio Suara Surabaya (@e100ss) dan berdasarkan keyword seperti 'kebakaran', 'macet', 'kecelakaan', dan 'banjir'. Alur untuk mendapatkan data dari Twitter ditunjukkan pada Gambar 1.

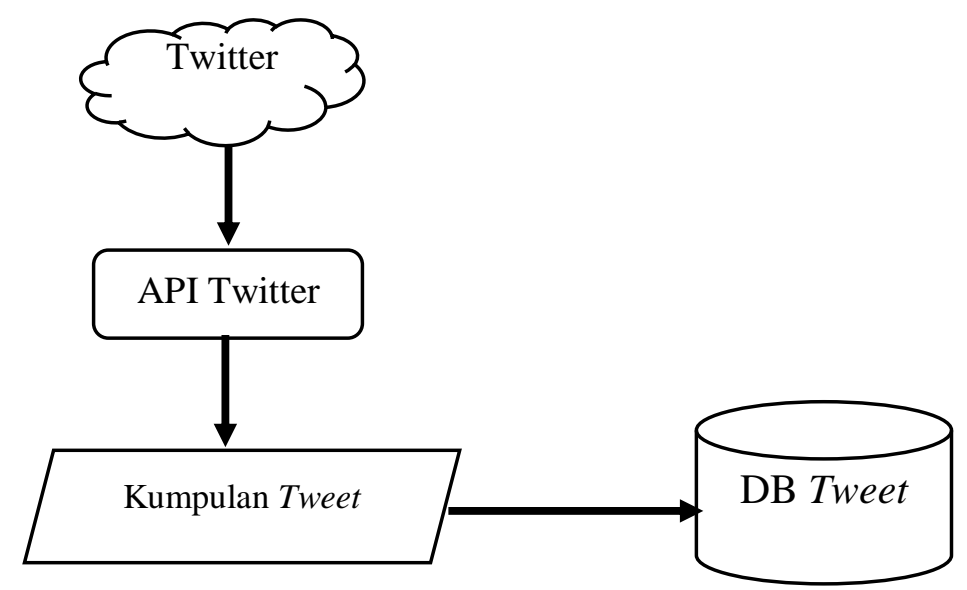

Gambar 1. Alur Pengambilan tweet dari Twitter.

\section{2) Data Gazetteer}

Selain data tweet dari pengguna Twitter yang memberikan informasi kejadian penting, juga dibutuhkan data gazetteer atau nama-nama tempat/lokasi di suatu lokasi. Dalam penelitian ini, peneliti memanfaatkan layanan peta open source yaitu OSM (open street map) untuk mendapatkan nama-nama tempat/lokasi yang berada di kota Surabaya. Alur pengambilan data gazetteer ditunjukkan pada Gambar 2.

Pengambilan data gazetteer menggunakan bantuan libray dari python yaitu xmltree karena struktur data dari OSM berupa XML. Xmltree memudahkan parsing struktur XML ke struktur teks sesuai kebutuhan. Data yang diperlukan dari OSM yaitu: 1) id lokasi, 2) kota, 3) alamat lokasi, 4) nama lokasi, 5) latitude dan longtitude. Semua data yang berhasil diambil disimpan ke dalam database mysql. Fungsi dari DB Gazetteer ini adalah untuk standardisasi nama lokasi pada proses Standardisasi Entitas Lokasi. 


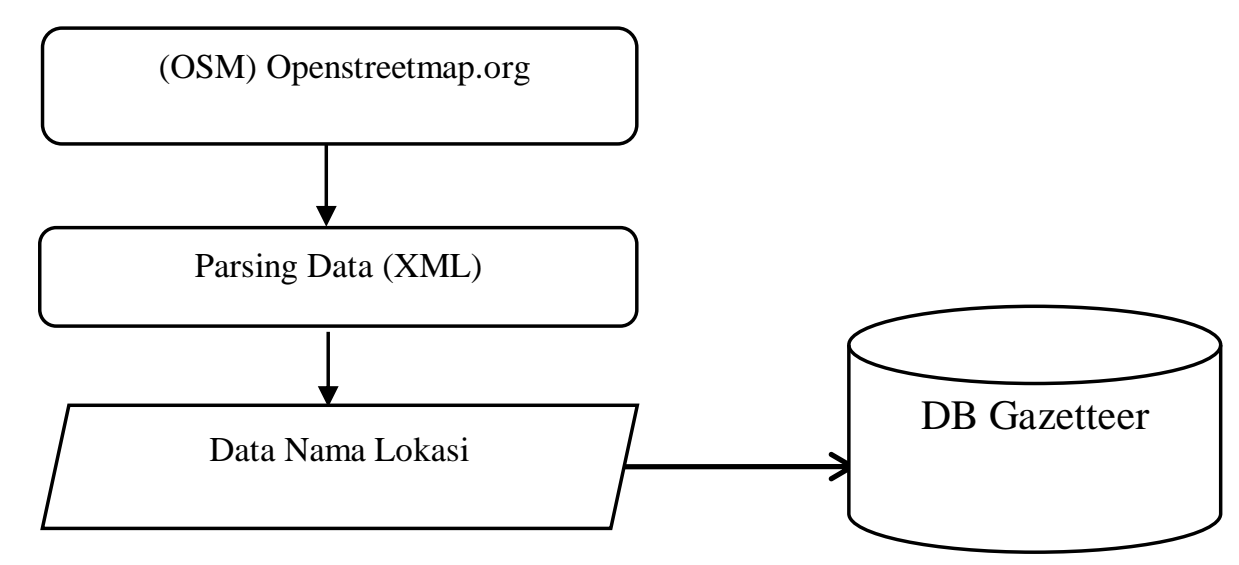

Gambar 2. Alur Pengambilan Data Gazetteer dari OSM.

\section{B. Standardisasi Entitas Lokasi}

Pada tahap ini tidak akan dibahas bagaimana proses penentuan entitas lokasi dan klasifikasi tweet kejadian. Proses penentuan entitas lokasi dan klasifikasi dapat dilihat pada penelitian (Putra \& Fatichah, 2018).

Standardisasi Entitas Lokasi adalah proses memperbaiki kesalahan penulisan nama lokasi yang pada penelitian ini menggunakan Fast approximate string matching (FASM) dengan yang merupakan modifikasi dari metode pencarian fuzzy string matching (FSM). Perbedaan dari keduanya adalah FASM memanfaatkan teknik edit distance Damerau-Levenshtein Distance, sedangkan FSM memanfaatkan teknik edit distance populer lainnya yaitu Levenshtein Distance untuk mencari string yang cocok dengan prediksi kemungkinan yang paling mendekati (bukan tepatnya atau pasti) (Garbe, 2015). FASM memiliki performa prediksi dan waktu komputasi yang lebih baik daripada fuzzy string matching standar. Contoh hasil pencarian perbaikan string menggunakan FASM ditunjukkan pada Tabel 1 .

Tabel 1 Contoh Pencarian Perbaikan String dengan FASM (Garbe, 2015)

\begin{tabular}{|l|l|l|l|l|}
\hline String & Best Correction & Edit Dist. & $\begin{array}{c}\text { Max. Edit } \\
\text { Dist. }\end{array}$ & $\begin{array}{c}\text { ms per 1000 } \\
\text { lookups }\end{array}$ \\
\hline zacamodation & accommodation & 4 & 4 & 727 \\
\hline acamodation & accommodation & 3 & 3 & 180 \\
\hline acomodation & accommodation & 2 & 2 & 33 \\
\hline hous & hous & 1 & 1 & 24 \\
\hline house & house & 0 & 1 & 1 \\
\hline
\end{tabular}

Proses standardisasi nama dilakukan menggunakan teknik FASM yang alur prosesnya ditunjukkan pada Gambar 3. Entitas nama lokasi yang berhasil dikenali oleh sistem akan dilakukan pencocokan string dari entitas tersebut menggunakan teknik FASM. Pencocokan atau matching memanfaatkan kamus database Gazetteer yang telah diperoleh sebelumnya. 


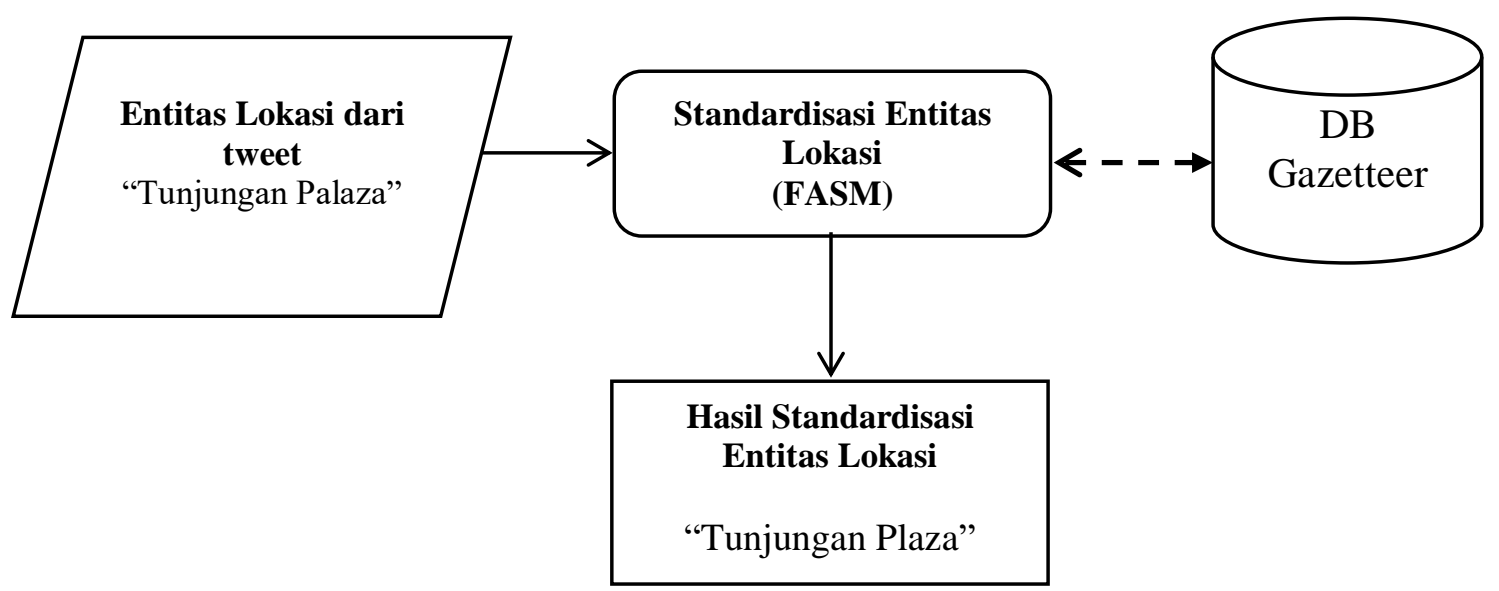

Gambar 3. Diagram Alur Standardisasi Entitas Nama Lokasi.

C. Konversi Lokasi Kejadian ke Dalam Bentuk Graf

Graf merupakan kumpulan node (V) bersama yang dihubungkan dengan edges (E) untuk menghubungan antar node (Hagberg, Schult, \& Swart, 2018). Suatu graf mempunyai kumpulan node $(V)$ yang terdiri dari $\{\mathrm{v} 1, \mathrm{v} 2, \mathrm{v} 3, \ldots, \mathrm{vn}\}$ dan edges $(E)$ yang menghubungkan antar node dalam $V$, dimana $E=\{e 1(v 1, v 2)$, e2(v2,v3), e3(v1,v3), en \}. Beberapa jenis graf antara lain: 1) directed-graph, 2) undirected-graph, dan 3) multi-graph.

Beberapa istilah khusus pada directed graph antara lain : 1) Successor, yaitu node $\mathrm{x}$ dihubungkan langsung ke node $\mathrm{y}(\mathrm{x}, \mathrm{y})$ dan y merupakan successor dari $\mathrm{x}, 2)$ Predecessor, node $\mathrm{x}$ dihubungkan langsung ke node $\mathrm{y}(\mathrm{x}, \mathrm{y})$ dan $\mathrm{x}$ adalah predecessor dari $\mathrm{y}$. Contoh graf berarah dengan 1 successor dan 1 predecessor ditunjukkan pada Gambar 4.

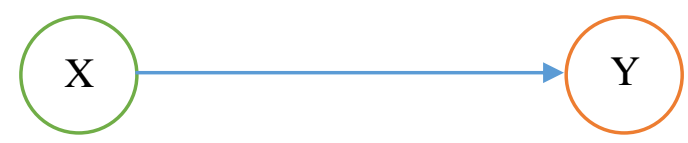

Gambar 4. Contoh Directed Graph dengan 1 Successor dan 1 Predecessor

Pada penelitian ini, setiap lokasi kejadian dinyatakan sebagai Node. Sedangkan edge merupakan relasi antar node yang didefinisikan menjadi 4 (empat) jenis relasi yaitu: 1) Highway-Position, 2) Street - Place, 3) StartingPoint - Destination, 4) Other. Setiap relasi tersebut memiliki perlakuan yang berbeda. Perlakuan setiap jenis relasi ditunjukkan pada Tabel 2.

Tabel 2 Perlakuan untuk masing-masing Relasi pada Graf

\begin{tabular}{|l|l|l|}
\hline No & Relasi & Perlakuan \\
\hline 1 & Highway-Position & $\begin{array}{l}\text { Penggabungan Node antara } \\
\text { Lokasi jalan Tol dengan } \\
\text { Posisinya. } \\
\text { Dan menghapus node posisi }\end{array}$ \\
\hline 2 & Street - Place & Penggabungan Node antara \\
\hline
\end{tabular}




\begin{tabular}{|l|l|l|}
\hline & & $\begin{array}{l}\text { Lokasi dengan Tempat. } \\
\text { Dan menghapus node } \\
\text { Tempat }\end{array}$ \\
\hline 3 & StartingPoint - Destination & $\begin{array}{l}\text { Node startingPoint } \\
\text { dihubungkan dengan Edge } \\
\text { ke node Destination }\end{array}$ \\
\hline 4 & Other & Tidak ada Relasi \\
\hline
\end{tabular}

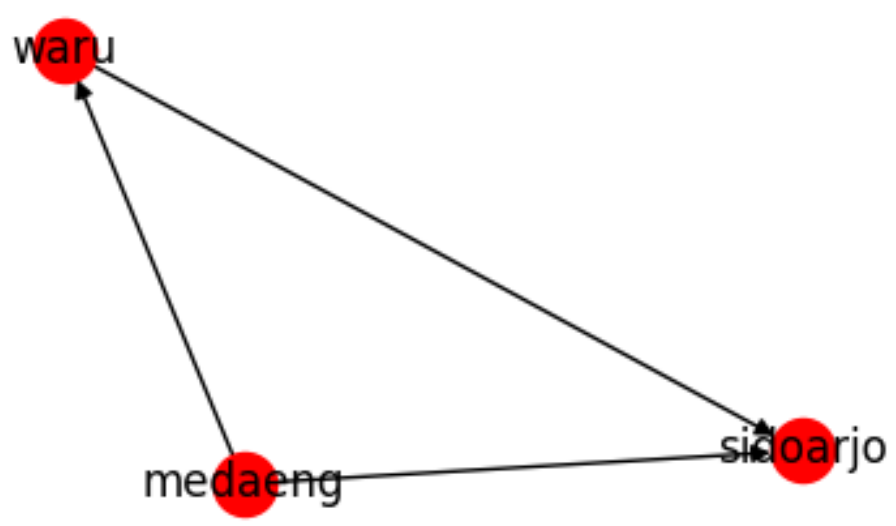

\section{Gambar 5 Contoh Konversi Hasil Ekstraksi Relasi ke Bentuk Graf}

Node dan edge yang sudah didapat akan dikonversi ke dalam bentuk graf yaitu directed-graph. Contoh hasil ekstraksi relasi jika diubah ke bentuk graf seperti pada Gambar 5. Hal ini dilakukan untuk mendapatkan node sebagai titik kejadian jika node tersebut berupa node tunggal, dan node sebagai titik awal bermula dari kejadian jika node tersebut memiliki hubungan dengan node yang lain. Jenis node yang berhubugan dengan node lainnya dibagi menjadi tiga jenis node yaitu: 1) node sebagai startingpoint, 2) node sebagai destination, 3) node sebagai waypoint.

Untuk menentukan siapa node yang menjadi startingpoing, destination, dan waypoint, digunakan konsep graf dengan menganalogikan startingpoint merupakan root dari sebuah graf, destination sebagai node akhir dari cabang graf, dan waypoint adalah node yang menghubungkan antara root dengan node akhir. Sebuah node dapat dijadikan sebagai root atau startingpoint jika node tersebut tidak memiliki predecessor dan sebaliknya memiliki successor. Kemudian untuk menentukan node sebagai destination adalah memilih node yang tidak memiliki successor namun memiliki predecessor. Sedangkan node yang mempunyai predecessor dan successor adalah merupakan waypoint. Node yang sudah dikenali dan diketahui jenis nodenya maka akan disimpan ke dalam database sebagai inputan pada tahap visualisasi data. Contoh hasil proses penentuan startingpoint, destination, dan waypoints ditunjukkan pada Gambar 6. 


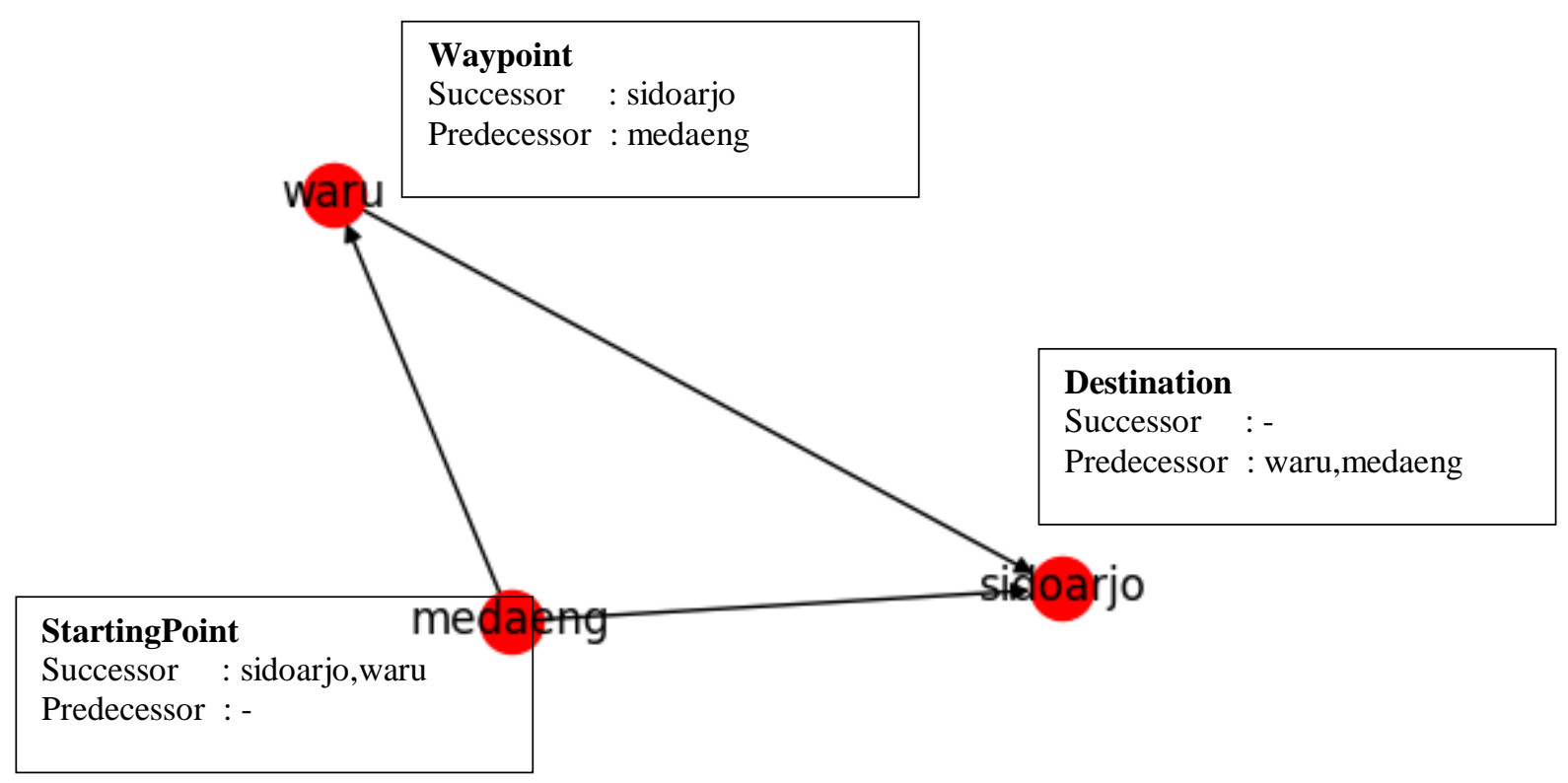

Gambar 6 Contoh Konversi Hasil Ekstraksi Relasi ke Bentuk Graf setelah melalui Proses Penentuan Startingpoint, Destination, dan Waypoint

\section{HASIL}

Uji coba dilakukan dengan menggunakan data tweet yang sudah tersimpan di database. Adapun batasan dalam uji coba ini adalah hanya menggunakan tweet yang berasal dari kota Surabaya. Pengujian dibagi menjadi dua yaitu uji kehandalan sistem dalam melakukan standardisasi entitas nama lokasi dan uji kehandalan sistem dalam konversi relasi antar lokasi kejadian ke dalam bentuk graf. Skenario pertama adalah menguji sistem menggunakan inputan tweet yang memiliki kesalahan penulisan entitas lokasi. Skenario kedua adalah menguji sistem dalam mengkonversi informasi ke dalam bentuk graf. Kedua Skenario tersebut dijabarkan sebagai berikut.

\section{Ujicoba Standardisasi Entitas Lokasi}

Pada ujicoba ini, data yang diproses adalah tweet informasi kejadian yang terdapat kesalahan penulisan entitas lokasi. Kesalahan penulisan nama tempat dalam sebuah tweet adalah hal yang wajar. Namun, dalam proses visualisasi nanti akan terjadi kendala geocoding oleh GoogleMaps karena nama lokasi tidak terdaftar atau dikenali sesuai standar penulisan nama tempat yang seharusnya. Beberapa tweet dengan kesalahan penulisan entitas nama lokasi ditunjukkan pada Tabel 3.

\section{Tabel 3. Hasil Standardisasi Entitas Lokasi}

\begin{tabular}{|l|l|}
\hline \multicolumn{1}{|c|}{ Entitas Lokasi } & \multicolumn{1}{c|}{ Hasil Standardisasi } \\
\hline Tnjungan Plasa & Tunjungan Plaza \\
\hline Surbaya & Surabaya \\
\hline Krtajya & Kertajaya \\
\hline Bnyu Urip & Banyu Urip \\
\hline
\end{tabular}

Dilain sisi, standardisasi entitas lokasi juga bisa justru mendapat hasil yang tidak sesuai. Hal ini bisa terjadi karena adanya penggunaan singkatan yang kurang tepat dalam penulisan nama lokasi. Selain itu, bisa juga dikarenakan penulisan nama lokasi sudah benar namun, karena tidak terdapat dalam kamus 
Gazetteer sehingga setelah melalui proses standardisasi nama, nama lokasi justru menjadi tidak sesuai dengan nama yang dimaksud dalam seuah tweet. Hal tersebut dapat dilihat pada Tabel 4. Kesalahan ini terjadi karena pada penelitian ini hanya menggunakan Gazetter wilayah kota Surabaya sehingga pencocokan nama akan dilakukan berdasarkan nilai edit distance terkecil.

\section{Tabel 4 Contoh Kesalahan dalam Proses Standardisasi Nama Gazetteer dengan FASM}

\begin{tabular}{|l|l|}
\hline \multicolumn{1}{|c|}{ Teks Tweet } & \multicolumn{1}{c|}{ Hasil Standardisasi } \\
\hline $\begin{array}{l}\text { lahan tebu ada api kebakaran di km } \\
\text { mojol tol sumo dari jombang ke }\end{array}$ & $\begin{array}{l}\text { ahan tebu ada api kebakaran di km } \\
\text { mog tol sumo dari kembang ke } \\
\text { mojokerto }\end{array}$ \\
\hline arah probolinggo macet parah & arah pro lingga macet parah \\
\hline
\end{tabular}

\section{Ujicoba Konversi Relasi Antar Lokasi ke Bentuk Graf}

Dalam satu tweet jika mempunyai lebih dari dua entitas maka akan memiliki lebih dari satu relasi, maka perlu didapatkan keterhubungan antar relasi yang terbentuk. keterhubungan antar relasi bisa didapatkan dengan mudah dengan mengubahnya kebentuk directed-graf. Contoh tweet yang memiliki lebih dari satu relasi ditunjukkan pada Gambar 7. Pada gambar tersebut didapatkan hasil ekstraksi seperti pada Gambar 8. Penentuan startingpoint, destination, dan waypoints dari hasil ekstraksi dengan memanfaatkan graf seperti ditunjukkan pada Gambar 9.

\section{Radio Suara Surabaya@e100ss·Jul 16 \\ elOO 09.34: \#JalurMACET}

1. Babatan Wlyung arah Citraland PADAT, imbas volume;

2. Kalianyar arah Undaan masih PADAT, antrean sampai Kusuma Bangsa;

3. Bundaran Aloha arah Waru lancar. (odp-hm)

Translate Tweet

Gambar 7. Contoh Tweet Kejadian dengan Entitas Lokasi lebih dari Dua $\langle e 1\rangle l o c\langle e 1\rangle$ arah $\langle e 2\rangle l o c\langle e 2\rangle$ masih padat antrean sampai loc $\langle e 1\rangle l o c\langle e 1\rangle$ arah loc masih padat antrean sampai <e2>loc<e2>

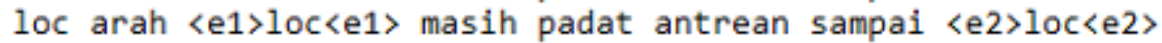
StartingPoint-Destination(e1,e2)

[5. 3.6.] 


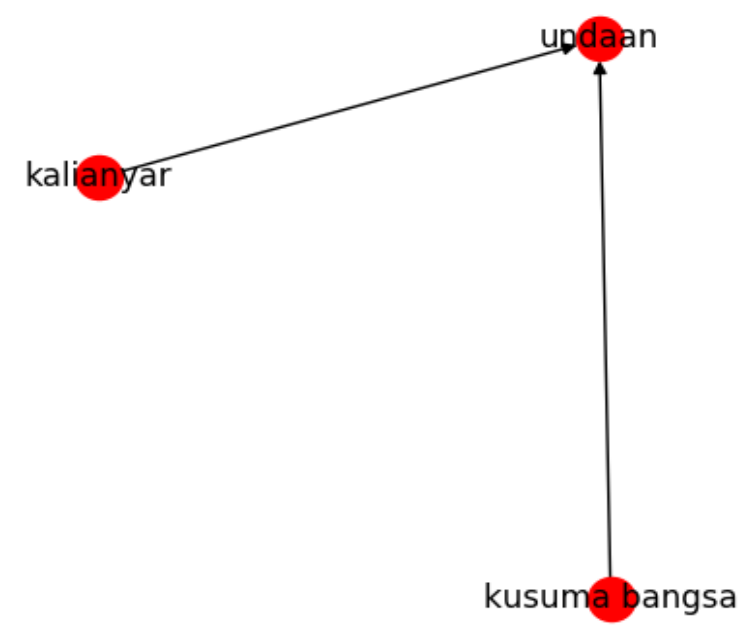

Gambar 9 Hasil Konversi Hasil Ekstraksi Relasi dalam Bentuk Graf

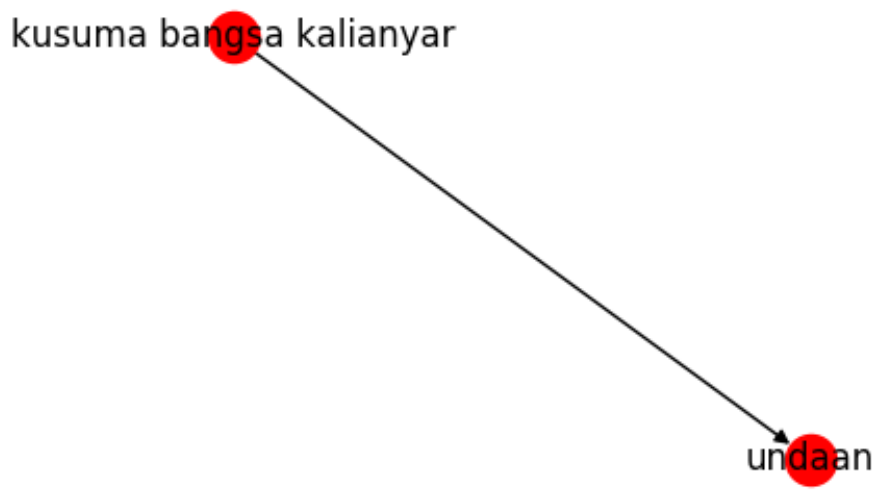

Gambar 10. Graf Hasil Penggabungan Node Kusuma Bangsa dan Kalianyar oleh Relasi Street-Place(e1,e2)

Dari Gambar 10 diterapkan perhitungan successor dan predecessor untuk menentukan node yang akan menjadi startingpoint dan destination. Berdasarkan hal tersebut dapat ditentukan bahwa kusuma bangsa kalianyar sebagai startingpoint dan undaaan sebagai destination. Hasil inilah yang digunakan sebagai inputan ke dalam GoogleMaps supaya informasi kejadian bisa dipetakan atau divisualisasikan secara tepat pada GoogleMaps. Hasil visualisasi informasi kejadian ditunjukkan pada Gambar 11. 


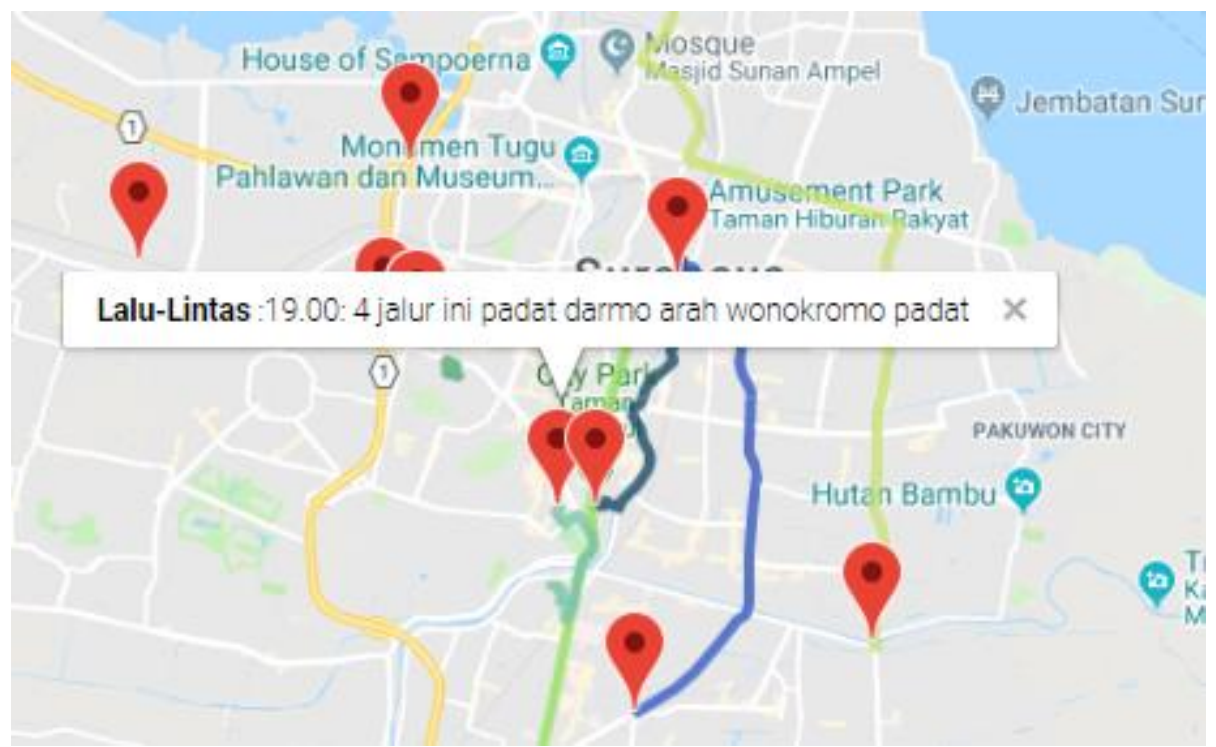

Gambar 11. Hasil Visualisasi Informasi Kejadian dalam GoogleMaps

\section{PEMBAHASAN}

Berdasarkan hasil pengujian di atas yaitu uji standardisasi dan uji konversi lokasi kejadian dalam bentuk graf, dapat dilihat bahwa sistem dapat bekerja sesuai tujuannya dan mengatasi permasalahan yang telah disampaikan di awal. Pada proses standardisasi dapat terlihat kesalahan penulisan entitas lokasi dapat dibetulkan sesuai penulisan yang seharusnya di dalam Gazetteer. Sedangkan pada, penggunaan graf sebagai langkah memodelkan lokasi-lokasi kejadian berdasarkan relasinya menunjukkan hasil yang sangat memuaskan. Kerumitan dalam memahami relasi antar lokasi dapat dengan mudah ditampilkan dalam sebuah graf berarah.

\section{KESIMPULAN}

Pemetaan atau visualisasi lokasi kejadian pada Sistem Deteksi Kejadian dengan data Twitter sebagai inputannya dapat dengan mudah dilakukan dengan proses standardisasi entitas lokasi yang kemudian dilakukan konversi ke dalam bentuk graf berdasarkan relasi antar lokasi. Maka, jika terdapat beberapa lokasi yang saling terhubung maka akan tebentuk sebuah graf berarah atau directed graph yang terdapat lokasi sebagai startingpoint, destination, dan atau waypoint yang kemudian dijadikan sebagai inputan dalam proses visualisasi lokasi ke dalam Google Maps.

\section{SARAN}

Pada pengembangan selanjutnya untuk pemrosesan input data tweet bisa dilakukan dengan menerapkan model antrian dan pemrosesan paralel. Jadi, sistem akan memproses tweet berdasarkan antriannya. Hal ini guna mengantisipasi tidak diprosesnya data tweet oleh sistem dikarenakan banyaknya data tweet yang masuk secara bersamaan.

\section{DAFTAR RUJUKAN}

Garbe, W. (2015). Fast approximate string matching with large edit distances in
Big
Data.
Retrieved
March
25
2018
from 
http://blog.faroo.com/2015/03/24/fast-approximate-string-matching-withlarge-edit-distances/

[Accessed: 25-Mar-2020]

Gelernter, J., \& Balaji, S. (2013). An algorithm for local geoparsing of microtext. GeoInformatica, 17(4), 635-667. https://doi.org/10.1007/s10707-012-0173-8

Gu, Y., Qian, Z., \& Chen, F. (2016). From Twitter to detector: Real-time traffic incident detection using social media data. Transportation Research Part C: Emerging Technologies, https://doi.org/10.1016/j.trc.2016.02.011

67 , 321-342.

Hagberg, A., Schult, D., \& Swart, P. (2018). NetworkX Reference.

Hasby, M., Khodra, M. L., \& Purwarianti, A. (2013). Optimal Path Finding based on Traffic Information Extraction from Twitter. In Prosiding International COnference on ICT for Smart Smart Society.

Li, J., He, Z., Plaza, J., Li, S., Chen, J., Wu, H., ... Liu, Y. (2017). Social Media: New Perspectives to Improve Remote Sensing for Emergency Response. Proceedings of the IEEE, 105(10), 1900-1912. https://doi.org/10.1109/JPROC.2017.2684460

Putra, F., \& Fatichah, C. (2018). Klasifikasi jenis kejadian menggunakan kombinasi NeuroNER dan Recurrent Convolutional Neural Network pada data Twitter, 4(2), 81-90. 